Division of Geological \& Geophysical Surveys

Raw Data Fie 1999-3

\title{
BIBLIOGRAPHY ON THE GEOLOGY OF THE HOLITNA LOWLAND AND SURROUNDING AREA
}

by

R.B. Blodget, D.L. LePain, J.G. Clough

September 1999

THIS REPORT HAS NOT BEEN REVIEWEO FOR TECHNICAL CONTENT (EXCEPT AS NOTED IN TEXT) OR FOR CONFORMITY TO THE EDTTORIAL STANDARDS OF DGGS.

Released by

STATE OF ALASKA

DEPARTMENT OF NATURAL RESOURCES

Division of Geological \& Geophysical Surveys

794 University Avenue, Suite 200

Fairbanks, Alaskn 99709-3645 


\section{$!$}




\title{
BIBLIOGRAPHY ON THE GEOLOGY OF THE HOLITNA LOWLAND AND SURROUNDING AREA
}

\author{
by Robert B. Blodgett1, David L. LePain², and James G. Clough² \\ 'Departments of Geosciences and Zoology; Oregon State University; Corvallis, Oregon \\ 97331 \\ ${ }^{2}$ Alaska Division of Geological \& Geophysical Surveys; 794 University Avenue, Suite \\ 200; Fairbanks, Alaska 99709
}

\section{Introduction}

The purpose of this bibliography is to provide a complete list of literature pertinent to the stratigraphy, regional geology, paleontology, and other geological aspects of the Holitna Lowland and adjoining region (Fig. 1). The study area, equivalent to what informally has been referred to as the "Holitna Basin" by petroleum geologists, includes the southeastern part of the Sleetmute Quadrangle, the northeastem part of the Taylor Mountains Quadrangle, and the northwestern portion of the Lime Hills Quadrangle. This list is a product of an on-going basin analysis of the region by the Alaska Division of Geological \& Geophysical Surveys (DGGS). Field work in assessing the petroleum potential of the Holitna Lowland was conducted by DGGS during the summers of 1983 and 1984, and was resumed in 1998. This region remains one of the most poorly known areas within Alaska in terms of its geology, and it is our hope that this bibliography will provide a starting point for those trying to better understand its character.

In this bibliography we provide references to all geological literature known to us from the region. In addition, we also provide citations to all pertinent stratigraphic, paleontologic, tectonic, and economic geologic literature from correlative rocks to the northeast in the Minchumina Lowlands, the northern Kuskokwim Mountains, and the northwest flank of the Alaska Range. These rocks are equivalent and conterminous with those present in the Holitna Lowland, but most have been offset by significant rightlateral motion along the Farewell segment of the Denali fault. Those rocks on the opposing side of the Farewell fault comprise what petroleum geologists have previously considered to the "Minchumina Basin", and include the physiographic provinces of the southern part of the Tanana-Kuskokwim Lowland and northem Kuskokwim Mountains. In terms of tectonostratigraphic nomenclature, these rocks include strata assigned to the Farewell terrane of Decker and others (1994), which includes the previously defined Nixon Fork, Dillinger, and Mystic subterranes. Both regions have been the subject of considerable field study and assessment by petroleum geologists during the early 1980's, but since so little remains published on these areas, we deemed it critical to provide a concise list of pertinent publications in order to provide a framework for future analysis of the region. The utility of such a list is especially evident in the paleontological literature, much of which has appeared in non-North American publications which are not readily available to American researchers. Comments have been added to end of several references where their significance may be unclear from the citation title. 


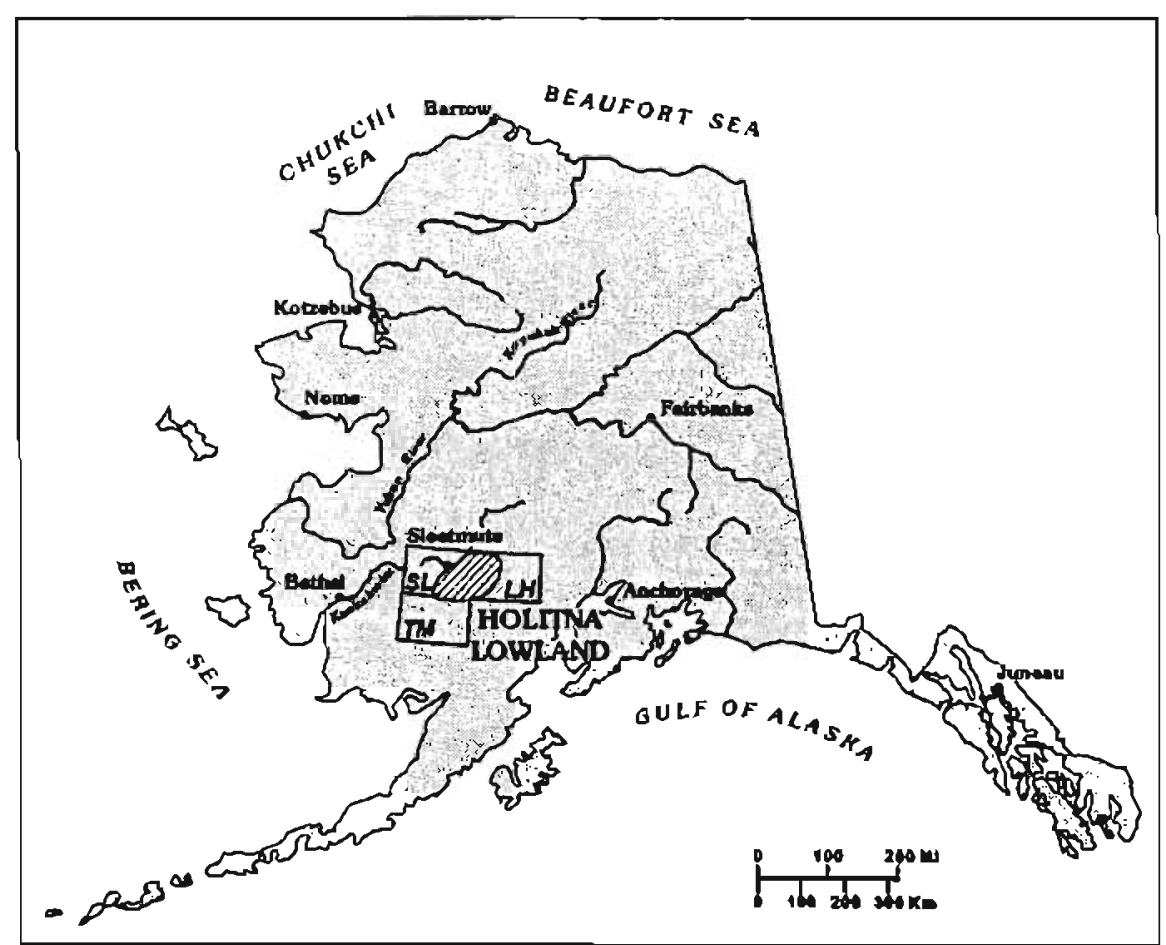

Figure 1. Map showing location of the Holitna Lowland (cross-hatched) in southwestern Alaska adjacent to the community of Sleetmute.

Outlines of Sleetmute (SL), Lime Hills (LH), and Taylor Mountains (TM) quadrangles shown with dotted lines.

\section{REFERENCES}

Abbott, Grant, 1995, Does Middle Cambrian rifting explain the origin of the Nixon Fork terrane?: Geological Society of America Abstracts with Programs, v. 27, no. 5, p. 1.

Adrain, J. M., Chatterton, B.D.E., and Blodgett, R.B., 1995, Silurian trilobites from southwestern Alaska: Journal of Paleontology, v. 69, p. 723-736.

Armstrong, A.K., Harris, A.G., Reed, B.L., and Carter, Claire, 1977, Paleozoic sedimentary rocks in the northwest part of the Talkeetna Quadrangle, Alaska Range, Alaska, in Blean, K. M., ed., The United States Geological Survey in Alaska; Accomplishments during 1976: U.S. Geological Survey Circular 751-B, p. B61-B62.

Babcock, L.E., and Blodgett, R.B., 1992, Biogeographic and paleogeographic significance of Middle Cambrian trilobites of Siberian aspect from southwestem 
Alaska: Geological Society of America Abstracts with Programs, v. 24, no. 5, p. 4.

Babcock, L.E., Blodgett, R.B., and St. John, James, 1993, Proterozoic and Cambrian stratigraphy and paleontology of the Nixon Fork terrane, southwestern Alaska: Proceedings of the First Circum-Pacific and Circum-Atlantic Terrane Conference, 5-22 November, 1993, Guanajuato, Mexico, p. 5-7.

Babcock, L.E., Blodgett, R.B., and St. John, James, 1994, New Late(?) Proterozoic formations in the vicinity of Lone Mountain, McGrath Quadrangle, west-central Alaska, in Till, A.B., and Moore, T.E., eds., Geologic Studies in Alaska by the U.S. Geological Survey, 1993: U.S. Geological Survey Bulletin 2107, p. 143-155.

Babcock, L.E., St. John, James, Jacobson, S.R., Askin, R.A., and Blodgett, R.B., 1995, Neoproterozoic to Early Paleozoic geologic bistory of the Nixon Fork Subterrane of the Farewell Terrane, Alaska. Geological Society of America Abstracts with Programs, 27, no. 5, p. 2.

Barnes, D.F., 1973, USGS Alaskan gravity data maps of Medfra and McGrath quadrangles: U.S. Geological Survey Open-File Report, 2 sheets, scale 1:250,000.

Bames, D.F., Olson, R.C., and Rambo, W.L., 1973, Tabulated gravity data from McGrath and Medfra quadrangles, Alaska: U.S. Geological Survey Open-File Report 73$17,32 \mathrm{p}$.

Baxter, M.E., and Blodgett. R.B., 1994, A new species of Droharhynchia from the lower Middle Devonian (Eifelian) of west-central Alaska: Journal of Paleontology, v. $68,0.1235-1240$.

Blodgett, R.B., 1983a, Paleobiogeographic implications of Devonian fossils from the Nixon Fork terrane, southwestern Alaska, in Stevens, C. H., ed., Pre-Jurassic rocks in western North America suspect terranes: Pacific Section, Society of Economic Paleontologists and Mineralogists, Los Angeles, p. 125-130.

Blodgett, R.B., 1983b, Paleobiogeographic implications of Devonian fossils from the Nixon Fork terrane, southwestern Alaska: Geological Society of America Abstracts with Programs, v. 15, no. 5, p. 428.

Blodget, R.B., 1983c, Paleobiogeographic implications of Devonian fossils from the Nixon Fork terrane, southwestern Alaska: Programs and Abstracts, Alaska Geological Society Symposium for 1983 (New developments in the Paleozoic geology of Alaska and the Yukon), p. 11-12.

Blodgett, R.B., 1992, Taxonomy and paleobiogeographic affinities of an early Middle Devonian (Eifelian) gastropod faunule from the Livengood quadrangle, eastcentral Alaska: Palaeontographica Abteilung A, v. 221, p. 125-168. [paper 
focuses on Middle Devonian gastropods from Livengood terrane, but many of these are also noted as being presented equivalent age strata of the McGrath and McGrath quadrangles].

Blodgett, R.B., 1993, Dutrochus, a new microdomatid (Gastropoda) genus from the Middle Devonian (Eifelian) of west-central Alaska: Joumal of Paleontology, v. 67, p. 194-197.

Blodgett, R.B., 1998, Emsian (Late Early Devonian) fossils indicate a Siberian origin for the Farewell terrane, in Clough, J.G. and Larson, F., eds., Short Notes on Alaskan Geology 1997: Alaska Division of Geological and Geophysical Surveys Professional Report I 18, p. 53-61.

Blodgett, R.B., and Boucot, A.J., 1999 (in press), Late Early Devonian (Late Emsian) eospiriferinid brachiopods from Shellabarger Pass, Talkeetna C-6 Quadrangle, south-central Alaska and their biogeographic importance; further evidence for a Siberian origin of the Farewell and allied Alaskan accreted terranes:

Senckenbergiana lethaea, v. 79(1).

Blodgett, R.B., and Brease, P.F., 1997, Emsian (late Early Devonian) brachiopods from Shellabarger Pass, Talkeetna C-6 quadrangle, Denali National Park, Alaska indicate Siberian origin for Farewell terrane: Geological Society of America Abstracts with Programs, v. 29, no. 5, p. 5.

Blodgett, R.B., and Clough, J.G., 1985, The Nixon Fork terrane: Part of an in-situ peninsular extension of the North American Paleozoic continent: Geological Society of America Abstracts with Programs, v. 17, no. 6, p. 342.

Blodgett, R.B., and Clough, J.G., 1987, The Devonian of interior Alaska: Second International Symposium on the Devonian System, Calgary, Alberta, Canada August 17-20, 1987, Program and Abstracts, p. 39.

Blodgett, R.B., Clough, J.G., and Smith, T.N., 1984, Ordovician-Devonian paleogeography of the Holitna Basin, southwestern Alaska: Geological Society of America Abstracts with Programs, v.16, no. 5, p. 271.

Blodgett, R.B., and Gilbert, W.G., 1983, The Cheeneetnuk Limestone; A new Early(?) to Middle Devonian formation in the McGrath A 4 and A-5 quadrangles, westcentral Alaska: Alaska Division of Geological and Geophysical Surveys Professional Report 85, 6 p, 1 sheet, scale 1:63,360.

Blodgett, R.B., and Gilbert, W.G., 1992, Upper Devonian shallow-marine siliciclastic strata and associated fauna and flora, Lime Hills D-4 quadrangle, southwest Alaska, in Bradley, D. C., and Dusel-Bacon, C., eds., Geologic Studies in Alaska by the U.S. Geological Survey, 1991: U.S. Geological Survey Bulletin 2041, p. 106-115. 
Blodgett, R.B. and Gilbert, W.G., 1992, Paleogeographic relations of Lower and Middle Paleozoic strata of southwest and west-central Alaska: Geological Society of America Abstracts with Programs, v. 24, no. 5, p. 8.

Blodgett, R.B., Gilbert, W.G., and Bundtzen, T.K., 1992, The Devonian of westem interior Alaska and its mineral resources: Intemational Symposium on Devonian System and its economic oil and mineral resources, Guilin, People's Republic of China, September 9-12, 1992, Abstract volume, p. 3-4.

Blodgett, R.B., and Johnson, J.G., 1992, Early Middle Devonian (Eifelian) gastropods of central Nevada: Palaeontographica Abteilung A, v. 222, p. 85-139 [although focus on paper is on Nevada, Devonian gastropods from the McGrath and Medfra quadrangles are also described].

Blodgett, R.B., and Johnson, J.G., 1994, First recognition of the genus Verneuilia Hall and Clarke (Brachiopoda, Spiriferida) from North America (west-central Alaska): Jounal of Paleontology, v. 68:1240-1242.

Blodgett, R.B., and Rokr, D.M., 1989, Two new Devonian spine-bearing pleurotomariacean gastropod genera from Alaska: Journal of Paleontology, v. 63, p. 47-52.

Blodgett, R.B., Rohr, D.M., and Boucot, A.J., 1988, Lower Devonian gastropod biogeography of the Western Hemisphere, in McMillan, N.J., Embry, A.F., Glass, D.J., eds., Devonian of the World: Canadian Society of Petroleum Geologists Memoir 14, v. 3, p. 285-305. [includes photos of Lower Devonian gastropods from Limestone Mountain, Medfra B-4 quadrangle].

Blodgett, R.B., Rohr, D.M., Measures, E.A., Savage, N.M., Pedder, A.E.H., and Chalmers, R.W., submitted, The Soda Creek Limestone, a new Upper Lower Devonian formation in the Medfra quadrangle, west-central Alaska: Short Notes on Alaskan Geology 1999: Alaska Division of Geological and Geophysical Surveys Professional Report.

Blodgett, R.B., Savage, N.M., Pedder, A.E.H., and Rohr, D.M., 1995, Biostratigraphy of an Upper Lower Devonian (Emsian) limestone unit at "Reef Ridge", Medfra B-3 quadrangle, west-central Alaska: Geological Society of America Abstracts with Programs, v. 27, no. 5, p. 6.

Blodgett, R.B., Sullivan, R., Clough, J.G., and LePain, D.L., 1999, Paleozoic paleontology of the Holitna Lowland, southwest Alaska: Geological Society of America Abstracts with Programs, v. 31, no. 6, p. A-39.

Brooks, A.H., 1911, The Mount McKinley district, Alaska: U.S. Geological Survey Professional Paper 70, $234 \mathrm{p}$. 
Brown, J.S., 1926, The Nixon Fork country: U.S. Geological Survey Bulletin 783-D, p. 97-144.

Bundtzen, T.K., and Gilbert, W.G., 1983, Outline of geology and mineral resources of the upper Kuskokwim region, Alaska, in Proceedings of the 1982 Symposium on Western Alaska Geology and Resource Potential: Joumal of the Alaska Geological Society, v. 3, p. 101-119.

Bundtzen, T. K., and Gilbert, W.G., 1991, Geology and geochemistry of the Gagaryah barite deposit, westem Alaska Range, Alaska, in Reger, R.D., ed., Short notes on Alaskan Geology-1991: Alaska Division of Geological and Geophysical Surveys Professional Report 111, p. 9-21.

Bundtzen, T.K., Harris, E.E., and Gilbert, W.G., 1997, Geologic map of the eastern half of the McGrath quadrangle, Alaska: Alaska Division of Geological and Geophysical Surveys Report of Investigations 97-14a, scale 1:250,000.

Bundtzen, T.K., Kline, J.T., and Clough, J.G., 1982, Preliminary geology of the McGrath B-2 quadrangle, Alaska: Alaska Division of Geological and Geophysical Surveys Open-File Report 149, 20 p., 1 sheet, scale 1:63,360.

Bundtzen, T.K., Kline, J.T., Smith, T.E., and Albanese, M.D., 1987, Geologic map of the McGrath A-2 quadrangle, Alaska: Alaska Division of Geological and Geophysical Surveys Professional Report 91, 20 p., 1 sheet, scale 1:63,360.

Bundtzen, T.K., Kline, J.T., Solie, D.N., and Clough, J.G., 1985, Geologic map of the McGrath B-2 quadrangle, Alaska: Alaska Division of Geological and Geophysical Surveys Public Data Data File 85-14, I sheet, scale 1:40,000.

Bundtzen, T.K., and Laird, G.M., 1983, Geologic map of the McGrath D-6 quadrangle, Alaska: Alaska Division of Geological and Geophysical Surveys Professional Report 79, 1 sheet, scale 1:63,360.

Bundtzen, T.K., Laird, G.M., Blodgett, R.B., Clautice, K.H., and Harris, E.E., 1994, Geology of the Gagaryah River area, Lime Hills C-5 and C-6 quadrangles, southwest Alaska: Alaska Division of Geological and Geophysical Surveys Public-Data File 94-40, 17 p., 1 sheet, scale 1:63,360.

Bundtzen, T.K., Laird, G.M., and Gilbert, W.G., 1989, Material studies along the Kuskokwim River, McGrath to Kalskag, southwest Alaska: Alaska Division of Geological and Geophysical Surveys Public-Data File 89-16, 84 p.

Cady, W.M., Wallace, R.E., Hoare, J.M., and Webber, E.J., 1955. The central Kuskokwim region, Alaska: U.S. Geological Survey Professional Paper 268, 132 p. 
Chalmers, R.W., Measures, E.A., Rohr, D.M., and Blodgett, R.B., 1995, Depositional environments of an upper Lower Devonian (Emsian) limestone unit at "Reef Ridge", Medfra B-3 quadrangle, west-central Alaska: Geological Society of America Abstracts with Programs, v. 27, no. 5, p. 6.

Churkin, M., Jr., 1973, Paleozoic and Precambrian rocks of Alaska and their role in its structural evolution: U.S. Geological Survey Professional Paper 740, 64 p.

Churkin, M., Jr., and Carter, Claire, 1996, Stratigraphy, structure, and graptolites of an Ordovician and Silurian sequence in Terra Cotta Mountains, Alaska Range, Alaska: U.S. Geological Survey Professional Paper 1555, 84 p.

Churkin, M., Jr., Reed, B.L., Carter, C., and Winkler, G.R., 1977, Lower Paleozoic graptolite section in Terra Cotta Mountains, southem Alaska Range, in Blean, K.M., ed., United States Geological Survey in Alaska; Accomplishments during 1976: U.S. Geological Survey Circular 751-B, p. B37-B38.

Churkin, M., Jr., Wallace, W.K., Bundtzen, T.K., and Gilbert, W.G., 1984, Nixon ForkDillinger terranes: A dismembered Paleozoic craton margin in Alaska displaced from Yukon Territory: Geological Society of America Abstracts with Programs, v. 16, no. 5 , p. 275.

Clautice, K.H., Bowman, N.C., Clough, J.G., Gilbert, W.G., Kline, J.T., Smith, T.E., and Blodgett, R.B., 1993, Land selection unit 8 (Kantishna River, Ruby, and Medfra quadrangles): references, lead isotope, geochemical and major oxide data: Alaska Division of Geological and Geophysical Surveys Public-Data File 93-8, 46 p., 1 sheet, scale $1: 250,000$.

Clough, J.G., and Blodgett, R.B., 1985, Comparative study of the sedimentology and paleoecology of middle Paleozoic algal and coral-stromatoporoid reefs in Alaska, in Gabrie, G., and Salvat, B., eds., Proceedings of the Fifth International Coral Reef Congress, Papeete, Tahiti, 1985, v. 2, (abstract), p. 78, v. 3, (text), p. 593 598.

Clough, J.G., and Blodgett, R.B., 1988, Silurian-Devonian algal reef mound complex of southwest Alaska, in Geldsetzer, H.H.J., James, N.P., and Tebbutt, G.E., eds., Reefs, Canada and adjacent areas: Canadjan Society of Petroleum Geologists Memoir 13, p. 404-407.

Clough, J.G., and Blodgett, R.B., 1992, A southwest Alaska Late Silurian-Early Devonian algal reef-rimmed carbonate ramp: depositional cycles and regional significance: Geological Society of America Abstracts with Programs, v. 24, no.5, p. 16.

Clough, J.G., Blodgett, R.B., and Smith, T.N., 1984, Middle Paleozoic shallow subtidal to intertidal sedimentation in Kulukbuk Hills, southwestern Alaska: Geological Society of America Abstracts with Programs, v. 16, no. 5, p. 275. 
Cobb, E.H., 1976, Summary of references to mineral occurrences (other than mineral fuels and construction materials) in the Iliamna, Lake Clark, Lime Hills and McGrath quadrangles, Alaska: U.S. Geological Survey Open-File 76-485, 101 p.

Crowder, K.L., and Decker, John, 1985, Provenance of conglomerate clasts from Upper Cretaceous Kuskokwim Group, southwest Alaska [abst.]: American Association of Petroleum Geologists Bulletin, v. 69, p. 660.

Decker, John, 1984, Geologic map of the Sparrevohn area: Alaska Division of Geological and Geophysical Surveys, Public-Data File 84-42, 2 sheets, scale 1:40,000.

Decker, John, Bergman, S.C., Blodgett, R.B., Box, S.E., Bundtzen, T.K., Clough, J.G., Coonrad, W.L., Gilbert, W.G., Miller, M.L., Murphy, J.M., Robinson, M.S., and Wallace, W.K., 1994, Geology of southwestern Alaska, in Plafker, George, and Berg, H.C., eds., The Geology of Alaska: Boulder, Colorado, Geological Society of America, The Geology of North America, v. G-1, p. 285-310.

Decker, J., and Dickey, D.B., 1984, Bibliography and index of southwestern Alaska geology: Alaska Division of Geological and Geophysical Surveys Public-Data File 84-50, $268 \mathrm{p}$.

Decker, J.E., and Hoare, J.M., 1982, Sedimentology of the Cretaceous Kuskokwim Group, southwest Alaska, in Coonrad, W.L., ed., The U.S. Geological Survey in Alaska; Accomplishments during 1980: U.S. Geological Survey Circular 844, p. 81-83.

Decker, John, Reifenstuhl, R.R., and Coonrad, W.L., 1984a, Compilation of geologic data from the Sleetmute B-5 quadrangle, southwestern Alaska: Alaska Division of Geological and Geophysical Surveys Public-Data File 88-44, 1 sheet, scale $1: 63,360$.

Decker, John, Reifenstuhl, R.R, and Coonrad, W.L., 1984b, Compilation of geologic data from the Sleetmute A-5 quadrangle, southwestem Alaska: Alaska Division of Geological and Geophysical Surveys Report of Investigations 84-29, 1 sheet, scale $1: 63,360$.

Decker, John, Reifenstuhl, R.R., and Coonrad, W.L., 1985, Compilation of geologic data from the Sleetmute A-7 quadrangle, southwestern Alaska: Alaska Division of Geological and Geophysical Survey Report of Investigations 85-1, 1 sheet, scale $1: 63,360$.

Decker, John, Reifenstuhl, R.R., Robinson, M.S., Waythomas, C.F., and Clough, J.G., 1995, Geology of the Sleetmute A-5, A-6, B-5, and B-6 quadrangles, southwestern Alaska: Alaska Division of Geological and Geophysical Surveys Professional Report 99, 16 p., 2 sheets, scalel:63,360. 
Decker, John, Robinson, M.S., Murphy, J.M., Reifenstuhl, R.R., and Albanese, M.D., 1984, Geologic map of the Sleetmute A-6 quadrangle: Alaska Division of Geological and Geophysical Surveys Report of Investigations 84-8, 1 sheet, scale $1: 40,000$.

Dickey, D.B., 1982, Tertiary sedimentary rocks and tectonic implications of the Farewell fault zone, McGrath Quadrangle, Alaska: Fairbanks, University of Alaska, M.S. thesis, $54 \mathrm{p}$.

Dickey, D.B., 1984, Cenozoic nonmarine sedimentary rocks of the Farewell fault zone, McGrath Quadrangle, Alaska: Sedimentary Geology, v. 38, p. 443-463.

Dickey, D.B., Gilbert, W.G., and Kline, J.T., 1982, Cenozoic non-marine sedimentary rocks and structure of the Farewell fault segment of the Denali fault system, southwest Alaska: Geological Society of America Abstracts with Programs, v. 14, no. 4, p. 160.

Dillon, J.T., and Patton, W.W., Jr., 1984, Boundary between the Ruby Geanticline and the Nixon Fork terrane: Geological Society of America Abstracts with Programs, v. 16, no. 5 , p. 279.

Dillon, J.T., Patton, W.W., Jr., Mukasa, S.B., Tilton, G.R., Blum, J., and Moll, E.J., 1985, New radiometric evidence for the age and thermal bistory of the metamorphic rocks of the Ruby and Nixon Fork terranes, west-central Alaska, in Bartsch-Winkler, S., and K. M. Reed, eds., The United States Geological Survey in Alaska; Accomplishments during 1983: U.S. Geological Survey Circular 945, p. 13-18.

Dutro, J.T., Jr., and Patton, W.W., Jr., 1981, Lower Paleozoic platform sequence in the Medfra Quadrangle, west-central Alaska, in Albert, N.R.D., and T. Hudson, eds., The United States Geological Survey in Alaska; Accomplishments during 1979: U.S. Geological Survey Circular 823-B, p. B42-B44.

Dutro, J.T., Jr., and Patton, W.W., Jr., 1982, New Paleozoic formations in the northem Kuskokwim Mountains, west-central Alaska: U.S. Geological Survey Bulletin 1529-H, p. H13-H22.

Elder, W.P., and Box, S.E., 1992, Late Cretaceous inoceramid bivalves of the Kuskokwim Basin, southwestem Alaska, and their implications for basin evolution: Journal of Paleontology, Memoir 26,39 p.

Eakin, H.M., 1918, The Cosna-Nowitna region, Alaska: U.S. Geological Survey Bulletin $667,54 \mathrm{p}$.

Ehm, Arlen, 1983, Oil and gas basins map of Alaska: Alaska Division of Geological \& Geophysical Surveys Special Report 32, 1 sheet, scale 1:2,500,000. 
Eppinger, R.G., 1994, Gold and cinnabar in heavy concentrates from stream sediment samples collected from westem half of Lime Hills 1:250,000 Quadrangle, Alaska, in Dusel-Bacon, C., and Till, A.B., eds., Geologic studies in Alaska by the U.S. Geological Survey, 1992: U.S. Geological Survey Bulletin 2068, p. 91-100.

Frýda, Jiøí, and Blodgett, R.B., 1998, Two new cirroidean genera (Vetigastropoda, Archaeogastropoda) from the Emsian (late Early Devonian) of Alaska with notes on the early phylogeny of Cirroidea: Journal of Paleontology, v. 72, p. 265-273.

Gates, G.O., Grantz, A., and Patton, W.W., Jr., 1968, Geology and natural gas and oil resources of Alaska, in Natural gases of North America: American Association of Petroleum Geologists Memoir 9, p. 3-48. [see p. 43 for discussion on petroleum potential in Kuskokwim (or Minchumina) lowland].

Gemuts, I., Puchner, C.C., and Steffel, C.I, 1983, Regional geology and tectonic history of western Alaska, in Proceedings of the 1982 Symposium on Western Alaska Geology and Resource Potential: Alaska Geological Society Journal, v. 3, p. 6782.

Gilbert, W.G., 1981, Preliminary geologic map of the Cheeneetnuk River area, Alaska: Alaska Division of Geological and Geophysical Surveys Open-File Report 153, 10 p., 2 sheets, scale 1:63,360.

Gilbert, W.G., and Bundtzen, T.K, 1983a, Paleozoic stratigraphy of Farewell area, southwest Alaska Range, Alaska, in Alaska Geological Society Symposium; New Developments in the Paleozoic Geology of Alaska and Yukon, Anchorage, Alaska, 1983: Alaska Geological Society Program and Abstracts, p. 10-11.

Gilbert, W.G., and Bundtzen, T.K., 1983b, Two-stage amalgamation of west-central Alaska: Geological Society of America Abstracts with Programs, v. 15, no. 5, p. 428.

Gilbert, W.G., and Bundtzen, T.K., 1984, Stratigraphic relationship between Dillinger and Mystic terranes, western Alaska Range, Alaska: Geological Society of America Abstracts with Programs, v. 16, no. 5, p. 286.

Gilbert, W.G., Bundtzen, T.K., Kline, J.T., and Laird, G.M., 1990, Preliminary geology and geochemistry of the southwest part of the Lime Hills D-4 quadrangle, Alaska: Alaska Division of Geological and Geophysical Surveys Report of Investigations $90-6,1$ sheet, scale $1: 63,360$.

Gilbert, W.G., and Solie, D.N., 1983, Preliminary bedrock geology of the McGrath A-3 quadrangle, Alaska: Alaska Division of Geological and Geophysical Surveys Report of Investigations 83-7, scale 1:40,000. 
Gilbert, W.G., Solie, D.N., and Dickey, D.B., 1982, Preliminary bedrock geology of the McGrath B-3 quadrangle, Alaska: Alaska Division of Geological and Geophysical Surveys Open-File Report 148, scale 1:40,000.

Gilbert, W. G., Solie, D. N., and Kline, J.T., 1988, Geologic map of the McGrath A-3 quadrangle, Alaska: Alaska Division of Geological and Geophysical Surveys Professional Report 92, 2 sheets, scale 1:63,360.

Gilbert, W.G., Solie, D.N., Kline, J.T., and Dickey, D.B., 1989, Geologic map of the McGrath B-3 quadrangle, Alaska: Alaska Division of Geological and Geophysical Surveys Professional Report 102, 2 sheets, scale 1:63,360.

Grant-Mackie, J.A., and Silberling, N.J., 1990, New data on the Upper Triassic bivalve Monotis in North America, and the new subgenus Pacimonotis: Joumal of Paleontology, v. 64, p. 240-254. [see p. 243, 250, 251, and 253].

Gray, J. E., Gent, C. A., Snee, L. W., and Wilson, F. H., 1997, Epithermal mercuryantimony and gold-bearing vein lodes of southwestern Alaska, in Goldfarb, R.J., and Miller, L.D., eds., Economic Geology Monograph, v. 9, p. 287-305.

Gray, J.E., and Theodorakos, P.M., 1997, Areas favorable for metallic mineral resources and newly discovered mineral occurrences in the Buckstock Mountains area, southwesterm Alaska, in Dumoulin, J.A., and Gray, J.E., eds., Geologic studies in Alaska by the U.S. Geological Survey, 1995: U.S. Geological Survey Professional Paper 1574, p. 111-123.

Grether, W. J., and Morgan, K. A., 1988, Exploration and hydrocarbon potential of interior basins, Alaska [abst.]: American Association of Petroleum Geologists Bulletin, v. 72, p. 191-192.

Hahn, Gerhard, Blodgett, R.B., and Gilbert, W.G., 1985, First recognition of the Gshelian (Upper Pennsylvanian) trilobite Brachymetopus pseudometopina Gauri and Ramovs in North America; and a description of accompanying trilobites from west-central Alaska: Joumal of Paleontology, v. 59, p. 27-31.

Hahn, Gerhard, and Hahn, Renate, 1985, Trilobiten aus dem hohen Ober-Karbon oder Unter-Perm von Alaska: Senckenbergiana lethaea, v. 66, p. 445-485.

Hahr, Gerhard, and Hahn, Renate, 1993, Neue Trilobiten-Funde aus dem Karbon und Perm Alaskas: Geologica et Palaeontologica, v. 27, p.141-163.

Hanks, C.L., Rogers, J.G., and Wallace, W.K., 1985, The westem Alaska Range flysch terrane; What is it and where did it come from?: Geological Society of America Abstracts with Programs, v. 17, no. 6, p. 359 . 
Henning, M.W., Meyer, J., Kornbrath, R., and Krouskop, D., 1984, Geologic and gravity valuation of oil and gas potential of the Minchumina Basin, Alaska: Geological Society of America Abstracts with Programs, v. 16, no. 5, p. 289.

Herreid, Gordon, 1966, Geology and geochemistry of the Nixon Fork area, Medfra quadrangle, Alaska: Alaska Division of Mines and Minerals Geologic Report 22, 34 p., 1 sheet, scale 1:40,000.

Hillhouse, J.W., and Coe, R.S., 1994, Paleomagnetic data from Alaska, in Plafker, G., and Berg, H.C., eds., The Geology of Alaska: The Geology of North America (DNAG), Volume G-1, p. 797-812. [see pp. 803-804].

Hoare, J.M, and Decker, J., 1981, Deep-water marine deposition of the Kuskokwim Group: U.S. Geological Survey Professional Paper 1275, p. 88-89.

House, M.R., and Blodgett, R.B., 1982, The Devonian goniatite genera Pinacites and Foordites from Alaska: Canadian Journal of Earth Sciences, 19:1873-187.

Jacobson, S., Blodgett, R.B., and Babcock, L.E., 1996, Organic matter and thermal maturation of Lower Paleozoic rocks from the Nixon Fork subterrane, westcentral and southwestem Alaska, in Moore, T. E., and Dumoulin, J. A., eds., Geologic Studies in Alaska by the U.S. Geological Survey, 1994: U.S. Geological Survey Bulletin 2152, p. 81-87.

Jasper, M.W., 1960, Report on Mespelt mine operation of Strandberg Mines, Inc. (Nixon Fork): Alaska Territorial Department of Mines, Properties Examined 65-1, 9 p., 2 sheets, scale 1:240.

Jasper, M.W., 1961, Mespelt mine, Medfra quadrangle: Alaska Division of Mines and Minerals 1961 Annual Report p. 49-58.

Johnson, J.G., and Blodgett, R.B., 1993, Russian Devonian brachiopod genera Cyrtinoides and Komiella in North America: Journal of Paleontology, v. 67, p. 952-958.

Jones, D.L., and Silberling, N.J., 1979, Mesozoic stratigraphy--The key to tectonic analysis of southern and central Alaska: U.S. Geological Survey Open-File Report 79-1200, $41 \mathrm{p}$.

Jones, D.L., and Silberling, N.J., 1982, Mesozoic stratigraphy - The key to tectonic analysis of southern and central Alaska, in Leviton, A.E., Rodda, P.U, Yochelson, E., and Adrich, M.L., eds., Frontiers of geological exploration of western North America: American Association for the Advancement of Science, Pacific Division, 60th Annual Meeting, University of Idaho, Moscow, Idaho, 1979, Proceedings [papers from two meeting symposiums], p. 139-153. 
Jones, D.L., Silberling, N.J., Berg, H.C., and Plafker, George, 1981, Map showing tectonostratigraphic terranes of Alaska, columnar sections, and summary description of terranes: U.S. Geological Survey Open-File 81-792, 20 p., 2 sheets, scale $1: 2,500,000$.

Jones, D.L., Silberling, N.J., Coney, P.J., and Plafker, George, 1987, Lithotectonic terrane map of Alaska (west of the 141st Meridan): U.S. Geological Survey Map MF-1874-A, 1 sheet, scale 1:2,500,000.

Jones, D.L., Silberling, N.J., Gilbert, W.G, and Coney, P.J., 1982, Character, distribution, and tectonic significance of accretionary terranes in the central Alaska Range: Journal of Geophysical Research, v. 87, p. 3709-3717.

Jones, D.L., Silberling, N.J., Gilbert, W.G, and Coney, P.J., 1983, Tectonostratigraphic map and interpretative bedrock geologic map of the Mt. McKinley region, Alaska: U.S. Geological Survey Open-File Report 83-11, scale 1:250,000.

Kingsbury, S. A., and Babcock, L. E., 1998, Biogeography and paleogeographic implications of early Middle Cambrian trilobites and enigmatic fossils from the Farewell terrane, southwestern Alaska: Geological Society of America Abstracts with Programs, v. 30, no. 2, p. 27.

Kirschner, C.E., 1994, Interior basins of Alaska, in Plafker, G., and Berg, H.C., eds., The Geology of Alaska: The Geology of North America (DNAG), Volume G-1, p. 469-493.

Kline, J.T., and Bundtzen, T.K., 1986, Two glacial records from west-central Alaska, in Hamilton, T.D., Reed, K.M., and Thorson, R.M., eds., Glaciation in Alaska-the geologic record: Alaska Geological Society Special Volume, p. 123-150.

Kline, J.T., Gilbert, W.G., and Bundtzen, T.K., 1986, Preliminary geologic map of McGrath C-1 quadrangle, Alaska: Alaska Division of Geological and Geophysical Surveys Report of Investigations 8-25, 1 sheet, scale 1:63,360.

Krause, K.J., 1984, Photointerpretive maps of morphological flood-plain deposits and materials resources, middle Kuskokwim River from Sleetmute to Kalskag, Alaska: Alaska Division of Geological and Geophysical Report of Investigations 84-2, 4 p., 5 sheets, scale 1:63,360.

Kriz, Jiøí, 1979, Silurian Cardiolidae (Bivalvia): Sbornik geologických vìd, Paleontologie, Volume 22, 157 p., 49 pls. [in English with Czech summary; p. 62 and p. 69 reports the questioned occurrence of the Wenlockian age Cardiola agna Kriz, from Wenlockian age limestones along the Jones River, collected by B. Reed in Dillinger subterrane rocks]. 
Lea, P.D., Buppert, G.D., and Waythomas, C.F., 1994, Last glacial eolian deposits in central and southwestern Alaska: Geological Society of America Abstracts with Programs, v. 26, no. 7, p. 512 .

Lea, P.D., and Elias, S.A., 1983, Late Quaternary environments of the Holitna Lowland, interior southwestern Alaska: Geological Society of America Abstracts with Programs, v. 15 , no. 6, p. 624-625.

Lea, P. D., and Waythomas, C. F., 1986, Late Pleistocene coversands in southwestern Alaska: American Quatemary Association; program and abstracts of the Ninth biennial meeting, v. 35a, no. 9, p. 93.

Lea, P.D., and Waythomas, C.F., 1990, Late Pleistocene eolian sand sheets in Alaska: Quaternary Research, v. 34, p. 269-281.

Lea, P. D., Waythomas, C. F., Walter, R. C., and Westgate, J. A., 1986, Distribution of Old Crow Tephra in southwestem Alaska; implications for the Old Crow eruption and the late Pleistocene glacial history of eastern Beringia: Geological Society of America Abstracts with Programs, v. 18, no. 6, p. 668.

LePain, D.L., Clough, J.G., Blodgett, R.B., Hanks, C.L., Ryherd, T., and Goldhammer, R.K., 1999, Stratigraphy, structure, and petroleum potential of the Holitna lowland area, southwest Alaska: AAPG Annual Convention, April 11-14, 199, San Antonio, Texas, Abstracts with Programs, p. A80.

Mamay, S.H., and Reed, B.L., 1984, Permian plant megafossils from the conglomerate of Mount Dall, central Alaska Range, in Coonrad, W.L., and Elliott, R.L., eds., The United States Geological Survey; Accomplishments during 1981: U.S. Geological Survey Circular 868, p. 98-102.

Mamet, B.L., and Plafker, George, 1982, A Late Devonian (Frasnian) Microbiota from the Farewell-Lyman Hills area, west-central Alaska: U.S. Geological Survey Professional Paper 1216-A, p. Al-A10.

Martin, G.C., 1921, Gold lodes of the upper Kuskokwim region, Alaska: U.S. Geological Survey Bulletin 722, $149 \mathrm{p}$.

Measures, E.A., Blodgett, R.B., and Rohr, D.M., 1992, Depositional setting and fauna of Middle Ordovician rocks of the Teisitna Formation, northern Kuskokwim Mountains, Alaska: Geological Society of America Abstracts with Programs, v. 24 , no. 5, p. 70 .

Measures, E.A., Rohr, D.M., and Blodgett, R.B., 1992, Depositional environments and some aspects of the fauna of Middle Ordovician rocks of the Telsitna Formation, northern Kuskokwim Mountains, Alaska, in Bradley, D. C., and Dusel-Bacon, C., 
eds., Geologic Studies in Alaska by the U.S. Geological Survey, 1991: U.S.

Geological Survey Bulletin 2041, p. 186-201.

Meyer, J.F., and Krouskop, D.L., 1984, Preliminary gravity data, Holitna Basin, southcentral Alaska: Alaska Division of Geological and Geophysical Surveys Report of Investigations 84-25, 6 p., 2 sheets, scale 1:500,000.

Meyer, J.F., and Krouskop, D.L., 1986, Preliminary gravity data of the Minchumina Basin, southcentral Alaska: Alaska Division of Geological and Geophysical Surveys Report of Investigations 86-1, 14 p., 2 sheets, scale 1:500,000.

Miller, M.L., Belkin, H.E., Blodgeth, R.B., Bundtzen, T.K., Cady, J.W., Goldfarb, R. J., Gray, J.E., McGimsey, R.G., and Simpson, S.L., 1989, Pre-field study and mineral resource assessment of the Sleetmute Quadrangle, southwestern Alaska: U.S. Geological Survey Open-File Report 89-363, 115 p., 3 pls.

Miller, M.L., and Bundtzen, T.K., 1988, Right-lateral offset solution for the IditarodNixon Fork fault, westem Alaska, in Galloway, J.P., and Hamilton, T.D., eds., Geologic studies in Alaska by the U.S. Geological Survey during 1987: U.S. Geological Survey Circular 1016, p. 99-103.

Moll, E.J., and Patton, W.W., Jr., 1982, Preliminary report on the Late Cretaceous and early Tertiary volcanic and related rocks in western Alaska, in Coonrad, W.L., ed., The U.S. Geological Survey in Alaska; Accomplishments during 1980: U.S. Geological Survey Circular 844, p. 73-76.

Moll, E.J., Silberman, M.L., and Patton, W.W., Jr., 1981, Chemistry, mineralogy, and KAr ages of igneous and metamorphic rocks of the Medfra quadrangle, Alaska. U.S. Geological Survey Open-File Report 80-811C, 19 p., 2 sheets, scale $1: 250,000$.

Moll-Stalcup, E.J., 1994, Latest Cretaceous and Cenozoic magmatism in mainland Alaska, in Plafker, George, and Berg, H.C., eds., The Geology of Alaska: Boulder, Colorado, Geological Society of America, The Geology of North America, v. G-1, p. 589-619.

Moore, T.E., and Wallace, W.K., 1985, Submarine-fan facies of the Kuskokwim Group, Caim Mountain area, southwestem Alaska: Geological Society of America Abstracts with Programs, v. 17, no. 6, p. 371.

Murphy, J.M., Decker, John, Reifenstuhl, R.R., and Coonrad, W.L., 1984, Compilation of geologic data from the Sleetmute B-6 quadrangle, southwestern Alaska: Alaska Division of Geological \& Geophysical Surveys Public-Data File 84-45, 1 sheet, scale 1:63,360. 
Nokleberg, W.J., Bundtzen, T.K., Berg, H.C., Brew, D.A., Grybeck, D., Robinson, M. S., Smith, T.E., and Yeend, W., 1987, Significant metalliferous lode deposits and placer districts of Alaska: U.S. Geological Survey Bulletin 1786, 104 p.

Nokleberg, W.J., Moll-Stalcup, E.J., Miller, T.P., Brew, D.A., Grantz, A., Reed, J.C., Jr., Plafker, G., Moore, T.E., Silva, S.R., Patton, W.W., Jr., with contributions on specific regions by Blodgett, R.B., Box, S.E., Bradley, D.C., Bundtzen, T. K., Dusel-Bacon, C., Gamble, B.M., Howell, D.G., Foster, H.L., Karl, S.M., Miller, M.L., and Nelson, S.W., 1994, Tectonostratigaphic terrane and overlap assemblage map of Alaska: U.S. Geological Survey Open-File Report 94-194, 53 p., 1 sheet, scale 1:2,500,000.

Nokleberg, W.J., Parfenov, L.M., Monger, J.W.H., Norton, I.O., Khanchuk, A.I., Stone, D.B., Scholl, D.W., and Fujita, K., 1998, Phanerozoic tectonic evolution of the Circum-North Pacific: U.S. Geological Survey Open-File Report 98-754, 125 p.

Nokleberg, W.J., and 40 others, 1984, Metallogeny and major mineral deposits of Alaska, in Plafker, George, and Berg, H.C., eds., The Geology of Alaska: Boulder, Colorado, Geological Society of America, The Geology of North America, v. G1, p. 855-903. [see pp. 865-867, 877].

Oliver, W.A., Jr., Merriam, C.W., and M. Churkin, Jr., 1975, Ordovician, Silurian, and Devonian corals of Alaska: U.S. Geological Survey Professional Paper 823-B, p. B13-B44.

Pacht, J.A., and Wallace, W.K., 1984, Depositional facies of a post-accretionary sequence--The Cretaceous Kuskokwim Group of southwestern Alaska. Geological Society of America Abstracts with Programs, v. 16, no. 5, p. 327.

Palmer, A.R., Egbert, R.M., Sullivan, R., and Knoth, J.S., 1985, Cambrian trilobites with Siberian affinities, southwestem Alaska [abst.]. American Association of Petroleum Geologists Bulletin, v. 69, p. 295.

Patton, W.W., Jr., 1976, Newly discovered Upper Triassic and Lower Cretaceous strata in the northern Kuskokwim Mountains, in Cobb, E.H., ed., The United States Geological Survey in Alaska; Accomplishments during 1975: U.S. Geological Survey Circular 733, p. 42-43.

Patton, W.W., Jr., 1978, Juxtaposed continental and ocean-island arc terranes in the Medfra quadrangle, west-central Alaska, in Johnson, K. M., ed., The United States Geological Survey in Alaska: Accomplishments during 1977: U.S. Geological Survey Circular 772-B, p. B38-B39.

Patton, W.W., Jr., Box, S.E., Moll-Stalcup, E.J., and Miller, T.P., 1994, Geology of southwestern Alaska, in Plafker, George, and Berg, H.C., eds., The Geology of 
Alaska: Boulder, Colorado, Geological Society of America, The Geology of North America, v. G-1, p. 241-269.

Patton, W.W., Jr., and Dutro, J.T., Jr., 1979, Age of the metamorphic complex in the northem Kuskokwim Mountains, west-central Alaska, in Johnson, K. M., and Williams, J. R, eds., The United States Geological Survey in Alaska; Accomplishments during 1978: U.S. Geological Survey Circular 804-B, p. B61B63.

Patton, W.W., Jr., Dutro, J.T., Jr., and Chapman, R.M., 1977, Late Paleozoic and Mesozoic stratigraphy of the Nixon Fork area, Medfra Quadrangle, Alaska, in Blean, K. M., ed., The United States Geological Survey in Alaska; Accomplishments during 1976: U.S. Geological Survey Circular 751-B, p. B38B40.

Patton, W.W., Jr., Moll, E.J., Dutro, J.T., Jr., Silberman, M.L., and Chapman, R.M., 1980, Preliminary geologic map of the Medfra Quadrangle, Alaska: U.S. Geological Survey Open-File Report 80-811A, 1 sheet, scale 1:250,000.

Patton, W.W., Jr., Moll, E.J., and King, H.H., 1984, The Alaskan mineral resource program; Guide to information contained in the folio of the geologic and mineral resources maps of the Medfra Quadrangle, Alaska: U.S. Geological Survey Circular 923, $11 \mathrm{p}$.

Plafker, George, and Berg, H.C., 1994, Overview of the geology and tectonic evolution of Alaska, in Plafker, George, and Berg, H.C., eds., The Geology of Alaska: Boulder, Colorado, Geological Society of America, The Geology of North America, v. G-1, p. 989-1021.

Plumley, P.W., 1987, Paleomagnetism and displacement of Alaskan terranes: Syracuse Scholar, v. 8 , no. 1, p. $36-50$.

Plumley, P.W., and Coe, R.S., 1982, Paleomagnetic evidence for reorganization of the north Cordilleran borderland in Late Paleozoic time: Geological Society of America Abstracts with Programs, v.14, no. 4, p. 224.

Plumley, P.W., and Coe, R.S., 1983, Paleomagnetic data from Paleozoic rocks of the Nixon Fork terrane, Alaska, and their tectonic implications: Geological Society of America Abstracts with Programs, v. 15, no. 5, p. 428.

Plumley, P.W., Coe, R.S., Patton, W.W., Jr., and Moll, E.J, 1981, Paleomagnetic study of the Nixon Fork terrane, west-central Allaska: Geological Society of America Abstracts with Programs, v.13, no. 7, p. 530. 
Poncet, Jacques, and Blodgett, R.B., 1987, First recognition of the Devonian alga Lancicula sergaensis Shuysky in North America (west-central Alaska): Journal of Paleontology, v. 61, p. 1269-1273.

Potter, A.W., 1984, Paleobiogeographic relations of Late Ordovician brachiopods from the York and Nixon Fork terranes, Alaska: Geological Society of America Abstracts with Programs, v. 16, no. 6, p. 626.

Potter, A.W., and Blodgett, R.B., 1992, Paleobiogeographic relations of Ordovician brachiopods from the Nixon Fork terrane, west-central Alaska: Geological Society of America Abstracts with Programs, v. 24, no. 5, p. 76.

Potter, A.W., Blodgett, R.B., and Rohr, D.M., 1988, Paleobiogeographic relations and paleogeographic significance of Late Ordovician brachiopods of Alaska: Geological Society of America Abstracts with Programs, v. 20, no. 7, p. 339.

Potter, A.W., Blodgett, R.B., and Rohr, D.M., 1988, Paleobiogeographic relations and paleogeographic significance of Late Ordovician brachiopods from Alaska: Fifth International Symposium on the Ordovician System, August 9-12, 1988, Memorial University of Newfoundland, St. John's, Newfoundland, Canada, Abstracts Volume, p. 74.

Potter, A.W., Gilbert, W.G., Ormiston, A.R., and Blodgett, R.B, 1980, Middle and Upper Ordovician brachiopods from Alaska and northern California and their paleobiogeographic implications: Geological Society of America Abstracts with Programs, v. 12, no. 3, p. 147.

Reed, B.L., and Eberlein, G.C., 1972, Massive sulfide deposits near Shellabarger Pass, southem Alaska Range: U.S. Geological Survey Bulletin 1342, 45 p.

Reed, B.L., and Nelson, S.W., 1980, Geological map of the Talkeetna quadrangle, Alaska: U.S. Geological Survey Miscellaneous Investigation Series Map I-1174, $15 \mathrm{p} ., 1$ sheet, scale $1: 250,000$.

Reed, K.M., Blome, C.D., Gilbert, W.G., and Solie, D.N., 1985, Jurassic radiolaria from the Lime Hills Quadrangle, in Bartsch-Winkler, S., and Reed, K.M., eds., The United States Geological Survey in Alaska; Accomplishments during 1983: U.S. Geological Survey Circular 945, p. 53-54.

Reifenstuhl, R.R., Decker, John, and Coonrad, W.L., 1985, Compilation of geologic data from the Taylor Mountains D-4 quadrangle: Alaska Division of Geological \& Geophysical Surveys Report of Investigations 85-2, 1 sheet, scale 1:63,360.

Reifenstuhl, R.R., Decker, John, Murphy, J.M., and Coonrad, W.L., 1984, Compilation of geologic data from the Sleetmute A-6 quadrangle, southwestern Alaska: Alaska 
Division of Geological and Geophysical Surveys Public-Data File 84-43, 1 sheet, scale $1: 63,360$.

Reifenstuhl, R.R., Robinson, M.S., Smith, T.E., Albanese, M.D., and Allegro, G.A., 1984, Geologic map of the Sleetmute B-6 quadrangle, Alaska: Alaska Division of Geological and Geophysical Survey Reports of Investigations 84-12, 1 sheet, scale $1: 40,000$.

Richards, R.W., 1995, A window on Ice Age environment: Mammoth Trumpet, v. 10, p. $17-20$.

Rigby, J.K., and Blodgett, R.B., 1983, Early Middle Devonian sponges from the McGrath quadrangle of west-central Alaska: Journal of Paleontology, v. 57, p. 773-786.

Rigby, J.K., Nitecki, M.H., Soja, C.M., and Blodgett, R.B., 1994, Silurian aphrosalpingid sphinctozoans from Alaska and Russia: Acta Palaeontologica Polonica, v. 39, p. 341-391.

Rigby, J.K., Potter, A.W., and Blodgett, R.B., 1988, Ordovician sphinctozoan sponges of Alaska and Yukon Territory: Journal of Paleontology, v. 62, p. 731-746.

Robinson, M.S., 1984a, Rock, pan-concentrate, and stream-sediment geochemistry, Sleetmute A-6 quadrangle: Alaska Division of Geological and Geophysical Surveys Report of Investigations 84-7, 1 sheet, scale 1:40,000.

Robinson, M.S., 1984b, Rock, pan-concentrate, and stream-sediment geochemistry, Sleetmute B-5 quadrangle: Alaska Division of Geological and Geophysical Surveys Report of Investigations 84-9, 1 sheet, scale 1:40,000.

Robinson, M.S., 1984c, Rock, pan-concentrate, and stream-sediment geochemistry, Sleetmute B-6 quadrangle: Alaska Division of Geological and Geophysical Surveys Report of Investigations 84-11, 1 sheet, scale 1:40,000.

Robinson, M.S., 1986, Basic statistical analysis of geochemical results for rock, panconcentrate, and stream-sediment samples from the Sleetrmute A-5, A-6, B-5, and B-6 quadrangles, southwest Alaska: Alaska Division of Geological and Geophysical Surveys Public-Data File 86-6, 81 p., three attached sheets (scale $1: 63,360$ ) are Reports of Investigations 84,7, 84-9, and 84- 11 .

Robinson, M.S., and Decker, John, 1986, Preliminary age dates and analytical data for selected igneous rocks from the Sleetmute, Russian Mission, Taylor Mountains and Bethel quadrangles, southwestern Alaska: Alaska Division of Geological and Geophysical Surveys Public-Data File 86-99, 8 p. 
Robinson, M.S., Decker, John, Reifenstuhl, R.R., Murphy, J.M., and Box, S.E., 1984a, Bedrock geology of the Chuilnuk and Kiokluk Mountains, southwest Alaska: Geological Society of America Abstracts with Programs, v. 16, no. 5, p. 330.

Robinson, M.S., Decker, John, Reifenstuhl, R.R., Murphy, J.M., and Box, S.E, 1984b, Geologic map of the Sleetmute B-5 quadrangle, Alaska: Alaska Division of Geological and Geophysical Surveys Report of Investigations 84-10, 1 sheet, scale $1: 40,000$.

Robinson, M.S., Nye, C.J., and Decker, John, 1986, Preliminary whole rock major oxide and trace element geochemistry of selected igneous rocks from the Sleetmute, Russian Mission, Taylor Mountains, and Bethel quadrangles, southwestern Alaska: Alaska Division of Geological and Geophysical Surveys Public-Data File 86-98, 8 p.

Roehm, J.C., 1937, Preliminary report of lode mining in the Nixon Fork district: Alaska Territorial Department of Mines Miscellaneous Reports 65-1, 11 p., 1 sheet, scale $1: 2,400$.

Rohr, D.M., 1993, Middle Ordovician carrier shell Lytospira (Mollusca, Gastropoda) from Alaska: Journal of Paleontology, v. 67, p. 959-962.

Robr, D.M., and Blodgett, R.B., 1985, Upper Ordovician Gastropoda from west-central Alaska: Journal of Paleontology, v. 59, p. 667-673.

Rohr, D.M., and Blodgett, R.B., 1988, First occurrence of Helicotoma Salter (Gastropoda) from the Ordovician of Alaska: Journal of Paleontology, v. 62, p. 304-306.

Rohr, D.M., Dutro, J.T., Jr., and Blodgett, R.B., 1991, Gastropods and brachiopods from the Ordovician Telsitna Formation, northern Kuskokwim Mountains, west-central Alaska: Sixth International Symposium on the Ordovician System - Abstracts University of Sydney, Sydney, Australia, July 15-19, 1991: Australia Bureau of Mineral Resources, Geology and Geophysical Record 1991/47, p. 29.

Rohr, D.M., Dutro, J.T., Jr., and Blodgett, R.B., 1992, Gastropods and brachiopods from the Ordovician Telsitna Formation, northern Kuskokwim Mountains, west-central Alaska, in Webby, B. D., and Laurie, J. R., eds., Global perspectives on Ordovician Geology, Proceedings of the Sixth International Symposium on the Ordovician System, Sydney, Australia: Balkema Press, p. 499-512.

Rohr, D.M., and Gubanov, A.P., 1997, Macluritid opercula (Gastropoda) from the Middle Ordovician of Siberia and Alaska: Joumal of Paleontology, v. 71, p. 394-400. 
Sainsbury, C.L., 1965, Previously undescribed Middle(?) Ordovician, Devonian(?), and Cretaceous(?) rocks, White Mountain area, near McGrath, Alaska: U.S. Geological Survey Professional Paper 525-C, p. C91-C95.

Sainsbury, C.L., and MacKevett, E.M., Jr., 1960, Structural control in five quicksilver deposits in southwestem Alaska, in Short papers in the geological sciences-Geological Survey research 1960: U.S. Geological Survey Professional Paper 400-B, p. B35-B38.

Sainsbury, C.L., and MacKevett, E.M., Jr., 1965, Quicksilver deposits of southwestern Alaska: U.S. Geological Survey Bulletin 1187,89 p.

St. John, J.M., 1994, Systematics and biogeography of some upper Middle Cambrian trilobites from the Holitna basin, southwestem Alaska: Columbus, Ohio, The Ohio State University, M.S. thesis, 90 p.

St. John, James, and Babcock, L.E., 1994, Biogeographic and paleogeographic implications of Middle Cambrian trilobites of extra-Laurentian aspect from a native terrane in south-western Alaska: Geological Society of America Abstracts with Programs, v. 26, no. 5, p. 63.

St. John, J.M., and Babcock, L.E., 1997, Late Middle Cambrian trilobites of Siberian aspect from the Farewell terrane, southwestern Alaska, in Dumoulin, J.A., and Gray, J.E., eds., Geologic studies in Alaska by the U.S. Geological Survey, 1995: U.S. Geological Survey Professional Paper 1574, p. 269-281.

Sandy, M. R., and Blodgeth, R. B., submitted, Early Jurassic spiriferid brachiopods from Alaska and paleogeographic significance: Geobios.

Savage, N.M., and Blodgett, R.B., 1995, A Late Emsian Amydrotaxis (Conodont) species from the Devonian of southwestern Alaska: Geological Society of America Abstracts with Programs, v. 27, no. 5, p. 6.

Savage, N.M., and Blodgett, R.B., 1995, A new species of the conodont Amydrotaxis from the Lower Devonian of southwestern Alaska, in Combellick, R.A., and Tannian, F., eds., Short notes on Alaska Geology 1995: Alaska Division of Geological and Geophysical Surveys Professional Report 117, p. 69-73.

Savage, N.M., Potter, A.W., and Gilber, W.G., 1983, Silurian and Silurian to Early Devonian conodonts from west-central Alaska: Joumal of Paleontology, v. 57, p. 873-875.

Savage, N.M., Rohr, D.M., and Blodgett, R.B., 1995, Late Silurian conodonts from the Medfra B-4 quadrangle, west-central Alaska: Geological Society of America Abstracts with Programs, v. 27, no. 5, p. 76. 
Schmidt, J.M., 1997, Shale-hosted Zn-Pb-Ag and barite deposits of Alaska, in Goldfarb, R.J., and Miller, L.D., eds., Economic Geology Monograph, v. 9, p. 35-65.

Schmidt, J.M., 1997, Strata-bound carbonate-hosted $\mathrm{Zn-Pb}$ and Cu deposits of Alaska, in Goldfarb, R.J., and Miller, L.D., eds., Economic Geology Monograph, v. 9, p. 90-119.

Shew, N., and Wilson, F.H., 1981, Map and table showing radiometric ages of rocks in southwestern Alaska: U.S. Geological Survey Open-File Report 81-866, 1 sheet, $26 \mathrm{p}$.

Short, S.K., Elias, S.A, Waythomas, C.F., Williams, N.E., and Lea, P.D., 1992, Fossil pollen and insect evidence for postglacial environmental conditions, Nushagak and Holitna Lowlands regions, southwestern Alaska: Arctic, v. 45, p. 381-392.

Silberling, N.A., Grant-Mackie, J.A., and Nichols, K.M., 1997, The Late Triassic bivalve Monotis in accreted terranes of Alaska: U.S. Geological Survey Bulletin 2151, 21 p.

Smith, P.S., 1917, The Lake Clark-central Kuskokwim region, Alaska: U.S. Geological Survey Bulletin 655, 162 p.

Smith, P.S., 1939, Areal geology of Alaska: U.S. Geological Survey Professional Paper $192,100 \mathrm{p}$.

Smith, T.N., Blodgett, R.B., and Clough, J.G., 1984, Stratigraphy and petroleum geology of the Holitna Basin, southwestern Alaska: Geological Society of America Abstracts with Programs, v. 16, no. 5, p. 334.

Smith, T.N., Clough, J.G., Meyer, J.F., and Blodgett, R.B., 1985, Petroleum potential and stratigraphy of Holitna Basin, Alaska [abst.]: American Association of Petroleum Geologists Bulletin, v. 69, p. 308.

Solie, D.N., 1983, The Middle Fork plutonic complex, McGrath A-3 Quadrangle, southwest Alaska: Alaska Division of Geological and Geophysical Surveys Report of Investigations 83-16, 17 p.

Solie, D.N., Bundtzen, T.K., and Gilbert, W.G., 1982, Upper Cretaceous-Lower Tertiary volcanic rocks near Farewell, Alaska, in Sciences in the North: Fairbanks, Arctic Division, American Association for the Advancement of Science, 33rd Alaska Science Conference, p. 138.

Solie, D.N., Bundtzen, T.K., and Gilbert, W.G., 1991, K-Ar ages of igneous rocks in the McGrath Quadrangle, Alaska: Alaska Division of Geological and Geophysical Surveys Public Data File Report 91-23, 8 p. 
Solie, D.N., and Dickey, D.B., 1982, Coal occurrences and analyses, Farewell-White Mountain area, Alaska: Alaska Division of Geological and Geophysical Surveys Open-File Report 160, 20 p., 1 sheet.

Spurr, J. E., 1900, A reconnaissance in southwestem Alaska in 1898: U.S. Geological Survey 20th Annual Report, part 7, p. 31-264.

Stanley, W.D., Labson, V.F., Nokleberg, W.J., Csejtey, B., Jr., and Fisher, M.A., 1990, The Denali fault system and Alaska Range of Alaska: Evidence for underplated Mesozoic flysch from magnetotelluric surveys: Geological Society of America Bulletin, v. 102, p. 160-173.

Stock, C.W., 1981, Cliefdenella alaskanensis n. sp. (Stromatoporoidea) from the Middle/Upper Ordovician of central Alaska: Journal of Paleontology, v. 55, p. 998-1005.

Szumigala, D.J., 1985, Geology of the Tin Creek zinc-lead skam deposits, McGrath B-2 quadrangle, Alaska: Alaska Division of Geological and Geophysical Survey Report of Investigations 85-50, $10 \mathrm{p}$.

Szumigala, D.J., 1987, Geology of zinc-lead skarn deposits in the Tin Creek area, McGrath B-2 quadrangle, Alaska: Alaska Division of Geological and Geophysical Survey Report of Investigations 87-5, 21 p., scale 1:5,000.

Thomas, B.I., 1948, Preliminary report of the Nixon Fork mining district: Alaska Territorial Department of Mines Miscellaneous Reports 65-2, 43 p., 2 sheets, scale $1: 250,000,1: 63,360$.

Throckmorton, M.L., and Patton, W.W., Jr., 1978, Contact-metasomatic magnetite deposit, Medfra quadrangle, Alaska: U.S. Geological Survey Open-File Report $78-26,13 \mathrm{p}$.

Tumer, D.L., Grybeck, D.G., and Wilson, F.H., 1975, Radiometric data from Alaska: A 1975 compilation: Alaska Division of Geological and Geophysical Surveys Special Report 10, 64 p.

U.S. Geological Survey, 1978, Aeromagnetic profiles of Holitna, Minchumina, Innoko, and Tanana lowlands, Alaska: U.S. Geological Survey Open-File 78-471, 7 sheets, scale $1: 250,000$.

Vance-Plumley, P., Plumley, P.W., Coe, R.S., and Reid, J., 1984, Preliminary paleomagnetic results from three Ordovician carbonate sections in the McGrath quadrangle, central Alaska: EOS Transactions of the Arnerican Geophysical Union, v. 65 , no. 45, p. 866 . 
Wahrhaftig, Clyde, 1965, Physiographic divisions of Alaska: U.S. Geological Survey Professional Paper 482, 52 p.

Wahrhaftig, Clyde, Bartsch-Winkler, S., and Stricker, G.D., 1994, Coal in Alaska, in Plafker, George, and Berg, H.C., eds., The Geology of Alaska: Boulder, Colorado, Geological Society of America, The Geology of North America, v. GI, p. 937-978.

Wallace, W.K., 1983, Major lithologic belts of southwestem Alaska and their tectonic implications: Geological Society of America Abstracts with Programs, v. 15, no. 5, p. 406-407.

Wallace, W.K., 1984, Mesozoic and Paleogene tectonic evolution of the southwestern Alaska Range; Southern Kuskokwim Mountains region: Geological Society of America Abstracts with Programs, v. 16, no. 5, p. 339.

Wallace, W.K., and Engebretson, D.C., 1982, Correlation between plate motions and Late Cretaceous to Paleocene magmatism in southwestern Alaska: EOS Transactions of the American Geophysical Union, v. 63, no. 45. p. 915.

Wallace, W.K., and Engebretson, D.C., 1984, Relationships between plate motions and Late Cretaceous to Paleocene magmatism in southwestern Alaska: Tectonics, $v$. 3, p. 295-315.

Wallace, W.K., Hanks, C.L., and Rogers, J.F., 1989, The southern Kahiltna terrane: implications for the tectonic evolution of southwestem Alaska: Geological Society of America Bulletin, v. 101. p. 1389-1407.

Waythomas, C. F., 1984, Quaternary glacial sequence in the Chuilnuk and Kiokluk Mountains, southwest Alaska: Geological Society of America Abstracts with Programs, v. 16, no. 5, p. 339.

Waythomas, C.F., 1988, Glacier reconstructions and late Quaternary paleoclimatic inferences, Chuilnuk and Kiokluk mountains, SW Alaska: Geological Society of America Abstracts with Programs, v. 20, no. 7, p. 208.

Waythomas, C.F., 1990, Quaternary geology and late-Quaternary environments of the Holitna Lowland and Chuilnuk-Kiokluk Mountains region, interior southwestern Alaska: Ph.D. dissertation, University of Colorado (Boulder), 305 p.

Waythomas, C. F., Lea, P. D., Walter, R. C., 1993, Stratigraphic context of Old Crow Tephra, Holitna Lowland, interior Southwest Alaska: Quaternary Research, v. 40, p. 20-29.

Wilson, F. H.., 1977, Some plutonic rocks of southwestern Alaska; A data compilation, 1977: U.S. Geological Survey Open-File Report 77-501, 9 p. 
Wilson, F.H., Dover, J.H., Bradley, D.C., Weber, F.R., Bundtzen, T.K., and Haeussler, P.J., 1998, Geologic map of Central (Interior) Alaska: U.S. Geological Survey Open-File Report 98-133, 63 p., appendix 13 p., 3 sheets, scale: 1:500,000. 